\title{
Martírio, rito e fetiche em Body Art e A refeição, de Newton Moreno
}

\author{
Martyrdom, Rite and Fetish in Body Art and The Meal, by Newton Moreno \\ Martirio, rito y fetiche en Body Art y A refeição, de Newton Moreno
}

Paula Regina Siega*

\section{Resumo}

Para Hans Robert Jauss, teórico da estética da recepção, o escritor é antes de tudo um leitor, situado em uma cadeia de recepções. Considerando a experiência da leitura como atividade capaz de gerar uma resposta criativa, Jauss entende a tradição literária como um processo de contínuo intercâmbio entre o velho e o novo, em que o presente relê o passado, atribuindo-lhe novas significações. Deste ponto de vista, abordamos o processo de recepção literária que consolida, no Brasil, uma tradição interpretativa em torno do tema da antropofagia, constantemente recuperado para assumir diferentes significados em diversos presentes históricos. Nesta tradição, colocamos a produção do dramaturgo pernambucano Newton Moreno que, com Body Art e A refeição: ensaios sobre o canibalismo, encena o corpo como suporte expressivo de ritos em que ressoam as práticas tribais da antropofagia. Tentaremos demonstrar, de um lado, os pontos de contato dessa dramaturgia com o passado literário nacional, e, do outro, as rupturas trazidas por uma releitura que integra o tema do canibalismo à ideia de corpo em sacrifício da Body Art e do teatro da crueldade de Artaud.

Palavras-chave: estética da recepção, canibalismo, dramaturgia contemporânea, Newton Moreno.

\begin{abstract}
For Reception Aesthetics theorist Hans Robert Jauss, the writer is first and foremost a reader, situated in a chain of receptions. Considering the experience of reading as an activity capable of generating a creative response, Jauss understands the literary tradition as a process of continuous exchange between the old and the new, in which the present may reread the past, attributing new meanings to it. From this point of view, we approach the process of literary reception that, in Brazil, is established as an interpretative tradition around the theme of anthropophagy, constantly revisited to assume different meanings in diverse historical moments. In this tradition, we locate the production of Newton Moreno, a playwright from Pernambuco, who with Body Art and Meal: essays on cannibalism, stages the body as an expressive prop of rites in which the tribal practices of anthropophagy resonate. On the one hand, we will try to demonstrate the points of contact of this dramaturgy with the national literary past and, on the other, the ruptures brought about by a rereading that integrates the theme of cannibalism with the idea of the body in sacrifice in Body Art and Artaud's theater of cruelty.
\end{abstract}

Keywords: reception aesthetics, cannibalism, contemporary dramaturgy, Newton Moreno.

\section{Resumen}

Para Hans Robert Jauss, teórico de la estética de la recepción, el escritor es en primer lugar un lector, situado en una cadena de recepciones. Considerando la experiencia de la lectura como una actividad capaz de generar una respuesta creativa, Jauss entiende la tradición literaria como un proceso de intercambio continuo entre lo viejo y lo nuevo, donde el presente relee el pasado, dándole nuevos significados. Desde este punto de vista, abordamos el proceso de recepción literaria que consolida, en Brasil, una tradición interpretativa en torno de la antropofagia, constantemente recuperada para asumir diferentes significados en diferentes contextos históricos. En esta tradición, situamos la producción del dramaturgo Newton Moreno, de Pernambuco, Brasil, que en Body Art e Refeição: ensaios sobre o canibalismo, representa el cuerpo como un soporte expresivo de los ritos en que resuenan las prácticas tribales de antropofagia. Trataremos de demostrar, por un lado, los puntos de contacto de esta dramaturgia con el pasado literario nacional $\mathrm{y}$, por otro lado, las rupturas provocadas por una relectura que integra el tema del canibalismo con la idea del cuerpo sacrificial del Body Art y el teatro de la crueldad de Artaud.

Palabras-clave: estética de la recepción, canibalismo, dramaturgia contemporánea, Newton Moreno.

\footnotetext{
"Universidade Estadual de Santa Cruz (UESC), Ilhéus, BA, Brasil. (Dorcid.org/0000-0002-6016-2445. E-mail: paula.siega@ gmail.com
} 


\section{Constante temática no cânone brasileiro: uma proposta a partir da estética da recepção}

Teorizada sobretudo por Hans Robert Jauss e Wolfgang Iser, a estética da recepção tem o mérito não somente de lançar luzes sobre a figura do leitor - visto não mais como mero componente sociológico e passivo do fenômeno literário - mas também o de esclarecer o elo indissociável entre recepção e produção. Enquanto Iser $(1987,1989)$ se ocupa do ato individual da leitura, Jauss realiza uma abordagem histórico-filológica interessada nas respostas do público e, se ambos consideram o receptor um elemento produtivo no processo de significação de um texto, Jauss (1994) sublinha a condição do escritor - assim como a do historiador e a do crítico - como leitor situado em uma cadeia de leituras sucessivas. ${ }^{1}$ Para Jauss $(1988,1989,1994)$, uma tradição - e, com ela, o cânone não se transmite por si, nem é um modelo épico de evoluções ou sucessão de criações espontâneas, mas um contínuo processo de recepção e produção: para que um texto continue a produzir efeitos no presente, deve ser acessado e atualizado por novas leituras, que podem dar ensejo a respostas criativas, materializadas em novos textos. Não existem, deste ponto de vista, sentidos e valores literários a priori que se perpetuam como entidades fixas, mas um continuum de seleção, significação e valoração operado pelos leitores, que enquadram o que leem no conjunto das próprias referências culturais, ao mesmo tempo que modificam tais referências a partir do que leem. Como sintetiza Roberto Reis (1992), a semantização do texto literário é produzida pela atividade da leitura, prática historicamente delimitada e fundamentalmente interpretativa que, situada no espaço da cultura, faz do texto uma teia em que se intersectam códigos, convenções e outro textos, mediando a nossa interação com a realidade.

Segundo Jauss, todo escritor responde à tradição que o precedeu conformando-se ao horizonte por ela estabelecido, recusando-o ou superando-o a partir de uma postura estética que inaugure novas expectativas. Anote-se que, para o estudioso, à ideia de postura estética se liga a de experiência estética, entendida como experimentação, no contato com a obra de arte, de um conhecimento verdadeiro do mundo e, como tal, transformador do sujeito. Nisto, segue a concepção de Hans-Georg Gadamer (2004), férreo contestador dos racionalismos que conferem à ciência o monopólio da verdade e do conhecimento. Daí a crença na função social da literatura que, para Jauss, não se limita a espelhar as transformações da estrutura econômica, mas é capaz de antecipar problemáticas que revelam ao sujeito o seu próprio devir. A ideia de que a experiência da leitura possa gerar diversas respostas, inclusive éticas, permite à estética da recepção situar um texto na cadeia de leituras que contribuíram para a sua realização: não se trata de reconstruir uma fonte originária, mas de inverter a perspectiva para perceber como os textos do passado foram lidos e transformados em outros textos.

Ao propor a combinação dos métodos diacrônico e sincrônico para a historiografia e a análise literárias, Jauss (1994) observa que, analogamente ao que acontece na história da língua, o sistema literário é constituído por elementos constantes, como o gênero, e elementos variáveis, como temas, motivos ou imagens literárias. Trata-se de uma abordagem que, ao entender a literatura como resultado de uma prática social, considera o gênero como um contrato implícito entre o horizonte de expectativas do público e o do autor (Pappalardo, 2009). A partir de suas pesquisas sobre os gêneros medievais - em particular, a passagem da canção de gesta ao romance cortês e ao romance alegórico -, o estudioso conclui que as estruturas formais dos gêneros permanecem relativamente constantes, sendo variáveis as funções a elas atribuídas a cada momento histórico (Mattei, 1988).

Diversos critérios de seleção, todavia, podem conduzir a outras conclusões em relação às constantes e às variáveis de um sistema literário. Em relação ao brasileiro, por exemplo, enquanto variam suportes formais, gêneros e estilos, permanecem relativamente estáveis certos temas neles representados. Esta constância temática é atestada pela historiografia literária, que identificou nos temas nativistas o princípio da formação da literatura brasileira, concluindo que a sua autonomia não se deu pela diferenciação em relação aos modelos formais das metrópoles, mas pelo que tais modelos passavam a expressar na colônia, ou seja, os assuntos e motivos da terra. Estes viriam a constituir, conforme José Aderaldo Castello (1965, p. 21) a "constante temática" herdada das

\footnotetext{
${ }^{1}$ Para uma análise comparativa entre Jauss e Iser, ver Adolfo Sánchez Vázquez (2005).
} 
manifestações literárias coloniais e continuada pela literatura vindoura, tendo no indianismo uma de suas expressões mais reconhecíveis.

À temática nativista vincula-se o tema da antropofagia, constantemente revisitado a partir de um processo de transmissão textual que, originado na prosa quinhentista sobre o Brasil, se estende até as experimentações literárias contemporâneas. Já Maria Cândida Ferreira de Almeida (2002, p. 18) identificou no topos canibal o "motivo que se repete e se fixou na tradição literária", vendo nele o traço identitário aglutinador de construções artísticas e teóricas expressas em variados suportes (textuais, pictóricos, musicais, cinematográficos, teatrais etc.). Almeida (2002) demonstra que a imagem do canibal se torna sinônimo das gentes dos brasis nos relatos coloniais, cimentando um imaginário que seria continuado ao longo da história até chegar à "atitude antropofágica" dos modernistas e, daí, ao século XXI.

A vitalidade da referida linha temática permite reconhecer a proposição de Jauss acerca da tradição como cadeia de recepções construída a partir dos confrontos com o passado e de reapropriações deste passado, de acordo com a sensibilidade estética do presente. Assim interpretado, o cânone não se configura como patrimônio simbólico imutável, mas como evento dinâmico em que cada época reconecta os fios com o que já se foi a partir de novas necessidades culturais, recompondo este cânone e integrando-se a ele - inclusive quando o contesta - cada vez de modo diverso. É nesta ótica que abordamos os textos Body Art e A refeição: ensaios sobre o canibalismo, de Newton Moreno, premiado autor pernambucano de teatro. Retomando algumas configurações do canibalismo em textos do passado, delineamos variações da postura estética de Moreno em relação à tradição que o precedeu, indicando na antropofagia uma realidade extinta que, atualizada através de novas leituras e representações literárias, confirma a sua relevância cultural para o cânone brasileiro.

\section{Breves considerações sobre topos canibal em O Caramuru (1781), "I-Juca Pirama" (1851) e "Manifesto antropófago" (1928)}

A literatura de informação produzida durante a colonização é constituída por uma prosa documental que revelava as condições de vida da colônia e a psicologia do colonizador, expressando o ambiente material e cultural do qual nasceria a experiência literária brasileira (Merquior, 2014). Essa literatura deu origem ao que o antropólogo Adone Agnolin (2002) interpreta como tecitura de um sistema de traduções culturais com as quais os europeus descreviam as alteridades que encontravam na América. Essa malha narrativa fez parte de uma operação discursiva configuradora do índio como contraponto funcional e ficcional ao modelo civilizatório europeu. É com esta função que a imagem do antropófago chega à poesia épica de Santa Rita Durão, que faz do canibalismo núcleo temático da caracterização das gentes brasílicas em $O$ Caramuru.

Saído do Brasil para a Europa ainda criança, Durão teve notícias das práticas canibais tupis através da leitura de Francisco de Brito Freire, Sebastião da Rocha Pitta e Simão de Vasconcellos, por sua vez receptores dos relatos de Nóbrega, Anchieta, Staden e Léry, entre outros. Esta cadeia de recepções contribuiu para que ecoassem, no poema, o imaginário inquisicionista que associava bruxaria e canibalismo, além das descrições de esquartejamento, cozimento e devoração dos corpos, numa configuração apta a transmitir à ideia do bárbaro comedor de carne humana. ${ }^{2}$

Muitos dos motivos indígenas d'O Caramuru seriam retomados por Gonçalves Dias em I-Juca Pyrama, leitor também dos escritos de Hans-Staden, Léry, Vieira e Simão de Vasconcellos, como se depreende das notas explicativas em Últimos cantos. Aludindo à prática canibal sem trazê-la à cena, o poeta romântico recobre-a de um sentido positivo, já que o destino do herói é interpretado como etapa de um rito guerreiro fundado sobre a honra. É demarcada, assim, uma nova postura ética em relação à antropofagia: considerada não mais do ponto de vista catequista, esta passa a

\footnotetext{
2 "Devora-se a infeliz mísera gente; | E, sempre reduzida a menos terra, | Virá toda a extinguir-se infelizmente. [...] E retalhando o corpo em mil pedaços, | Vai cada um famélico trazendo, | Qual um pé, qual a mão, qual outro os braços | Outros da crua carne iam comendo; | Tanto na infame gula eram devassos Tais há, | que as assam nos ardentes fossos, | Alguns torrando estão na chama os ossos" (Durão, 1781, p. 10-14).
} 
ser compreendida como prática religiosa de um povo extinto. Gonçalves Dias, um dos primeiros etnólogos brasileiros, antecipava deste modo as interpretações que seriam desenvolvidas no séc. $X X$ por estudiosos ${ }^{3}$ que passaram a sublinhar a valência simbólica de um rito no qual a devoração do outro era também sua assimilação cultural.

I-Juca Pyrama devolve ao rito antropófago uma parte de sua dignidade religiosa e festiva - tratavase de "bárbara usança", mas também de "honrosa função" (Dias, 1851, p. 14) -, mas é exatamente por causa desse novo olhar que as descrições do canibalismo são evitadas. No poema romântico, as fases rituais do sacrifício e devoração são sublimadas em imagens que dão a entender o que ocorrerá ao guerreiro, sem que para isso ocorra a descrição verbal da antropofagia. O leitor familiarizado com a história colonial compreende que o canibalismo é parte do rito, mas essa compreensão faz parte de um acordo tácito entre receptor e poeta, que se cala sobre a realidade material da execução e deglutição corporais. Renovando a temática do canibalismo, Gonçalves Dias "eleva" o antropófago à condição trágica, recusando os traços grotescos dos quais se valera a prosa colonial para a representação do indígena. Em consonância com a proposição jaussiana, se confirma um olhar seletivo sobre o passado, em que, a um tema já conhecido, são atribuídas novas funções, em sintonia com a retórica nacionalista que procurava nobilitar a genealogia do povo brasileiro.

Superado pelo realismo, o romantismo seria revisitado pelos modernistas, que releriam em chave irônica muitos dos tópicos erigidos pelas interpretações indianistas do passado nacional. Expressiva desta tendência é a Revista de Antropofagia, que divulga, entre 1928 e 1929, as direções tomadas pela elite intelectual brasileira, receptora tanto das inovações das vanguardas europeias como da tradição literária local. A pretendida síntese entre estes dois mundos é dada pelo próprio título da revista que, na referência ao canibalismo tupi, metaforiza a deglutição cultural de um "outro" identificado com o europeu. É este o sentido que vem adquirir a frase "Aí vem a nossa comida pulando". Originária do relato de Hans Staden sobre a sua captura pelos tupinambás, ela integra visualmente o editorial de Antônio de Alcântara Machado (1928, p. 1) que, com analogias entre canibais, diródimos e xipófagos, acena a um processo de diversificação cultural no qual permanecia a lembrança do vínculo original: "O antropófago: nosso pai, princípio de tudo".

Aplicada como princípio estético, a antropofagia modernista pretendia a assimilação cultural de outros textos, minando a ideia de uma "fonte original" - localizada, sempre, na Europa - e eliminando, portanto, a ideia de um débito cultural com a metrópole. Tratava-se, como afirma Haroldo de Campos (1992, p. 234) em Da razão antropofágica, de afirmar a possibilidade de "elaboração crítica do legado cultural universal", recebido não na perspectiva romântica do bom e pacífico selvagem, mas do antropófago desabusado, num ato não de submissão à cultura europeia, mas de transculturação. A teoria encontrava aplicação em "Tupy or not tupy, that is the question", frase paródica que integra o Manifesto Antropófago, no qual Oswald de Andrade legitimava a ideia de que beber em fontes externas não invalidava a cultura nacional. Tornando-se mais célebre do que a própria revista, o manifesto reconhecia a antropofagia como traço cultural propiciador da tão proclamada unidade nacional. Não se tratava de expurgar o estrangeiro, mas de devorá-lo em um processo ambivalente, que transformava o que era proibido (a devoração do outro / o consumo da cultura estrangeira) em monumento de celebração: "Antropofagia. A transformação permanente do Tabu em totem" (Andrade, 1928, p. 3).

É evidente a referência a Totem e tabu, de 1913, no qual Sigmund Freud apresentava a ideia de banquete totêmico, concluindo que para formar um totem era necessário quebrar um tabu. Partindo de Darwin, Freud (2002) considera que, em sociedades canibais pré-matriarcais, o pai era o déspota que eliminava e expulsava os filhos machos, ameaças ao seu poder sob o clã, até que a irmandade dos expulsos se uniu para matar e comer aquele que impedia a realização dos seus desejos sexuais. Ao devorar o pai, cada filho dava vazão ao ódio pelo tirano e ao mesmo tempo se identificava com a figura paterna, apropriando-se de parte de sua força. Em seguida, tomados pelo remorso filial, davam vazão a um sentimento de culpa através do qual o morto tornava-se mais potente do que o vivo. Em obediência póstuma, os filhos renegavam o próprio ato, proibiam a eliminação do totem, substituto do pai, e renunciavam às relações sexuais com as

${ }^{3}$ Os mais conhecidos são Florestan Fernandes (2006), Viveiro de Castro (1986) e Darcy Ribeiro (2006). 
mulheres dele. Fundavam-se assim os dois tabus da civilização, que coincidiam com os desejos removidos do complexo de Édipo: o incesto e o parricídio.

Leitor do psicanalista austríaco, Oswald de Andrade (1928, p. 7) situa a sua tese em oposição a ele ao afirmar que "só as puras elites conseguiram realizar a antropofagia carnal, que traz em si o mais alto sentido da vida e evita todos os males identificados por Freud, males catequistas". Tais males seriam os tabus primordiais que, para o brasileiro, não poderiam ser estendidos às sociedades alheias ao panteão judaico-cristão. Os antropófagos eram assim alçados às mais "altas elites", num ato ao mesmo tempo conservador e subversivo, já que mantinha o caráter de superioridade cultural da elite, mas deslocava-a da civilização europeia para as civilizações indígenas. Oswald fazia, assim, com que o canibalismo primitivo deixasse de ser tabu para retornar à festa totêmica: “Antropofagia. Absorção do inimigo sacro. Para transformá-lo em totem" (Andrade, 1928, p. 7).

Considerando a produção literária e cultural do século XX e XXI, a afirmação oswaldiana pode ser considerada uma profecia. Desde o modernismo, o tema da antropofagia se multiplicou em obras que revisitaram o passado indígena ou a literatura que o representou, conforme já observado por Almeida (2002). Entre os exemplos mais recentes desta releitura está a produção dramática de Newton Moreno, continuador de uma tradição que cimenta a figura do antropófago como elemento significativo da cultura letrada nacional. Pós-modernista, o dramaturgo delimita uma ulterior mudança de postura em relação às leituras do passado, transpondo o tema da antropofagia aos suportes expressivos do teatro e da performance. Ao fazê-lo, atualiza a temática literária do passado, buscando nela sentidos atuais e intentando rupturas conceituais através da recepção de linhas expressivas externas, especificamente, os legados da Body Art e do teatro da crueldade, de Artaud.

\section{Corpo sacrificial, rito e canibalismo em Body Art e A refeição, de Newton Moreno}

Para a Body Art, tendência estética que ganha força nos anos 1970, o corpo é suporte material da criação artística, forma de linguagem que se expressa através de performance e de modificações corporais tais como pintura, tatuagens, piercings, lacerações, implantes etc. Uma das primeiras a propor um entendimento do fenômeno, Lea Vergine (2003) afirma que na base da nova corrente estava uma carga de agressividade derivante da frustração do desejo de amor e de aceitação por parte de artistas e intelectuais que, provenientes da burguesia, mas em choque com seus valores, tratavam de recriar uma cultura não convencional através do acento nos aspectos físicos, orgânicos ou primários da natureza.

Na busca por um nexo profundo com o corpo reside um dos principais vínculos da Body Art com o teatro da crueldade que Antonin Artaud desenvolvera nos anos 1930. Artaud concebia a representação teatral como cerimônia sacra de purificação: tratava-se de um ritual de morte e renascimento que encenava oniricamente as forças vitais e inconscientes do indivíduo movido por cargas de violência, terror e crueldade (Artioli, 2004). Numa visão terapêutica do teatro, este passava de evasão burguesa a meio de ação concreta, voltada à transformação da realidade e da condição humana (Virmaux, 1990), e por isso era comparado à crise corporal desencadeada pela doença. A cena seria o momento de um ataque ao corpo, diante do qual se abriam as vias da morte ou da regeneração:

$$
\begin{gathered}
\text { o teatro } \\
\text { o lugar, o estado } \\
\text { o ponto, }
\end{gathered}
$$

onde se aprende a anatomia humana, e através dela se cura e se rege a vida. (Artaud, 1990, p. 325)

Para Lea Vergine (2003), é uma perspectiva semelhante àquela de Artaud que leva os artistas da Body Art a buscarem o autoconhecimento a partir da experimentação do corpo, despojandoo das convenções para fazê-lo renascer em experiências autênticas, cruéis e dolorosas. Ao reivindicar aceitação, a Body Art comunica uma realidade íntima, exibindo detalhes da esfera 
pessoal da existência - fotos, raios- $x$, ferimentos, relações com excrementos ou genitálias, representações dos próprios sonhos ou da história familiar - destruindo as separações entre público e privado (Vergine, 2003). Nesse jogo com o público, são exploradas as relações entre representação e regressão psicológica, na reelaboração de mitos ou traumas individuais que portam à luz um sujeito desarmado das significações coletivas da cultura. Trata-se de um "homo" que não é "nem faber, nem ludens, nem sapiens", sem mitos nem moralidade, e que:

vive seus atos de piedade e obscenidade, com seus vermelhos e impuros intestinos, com seu gosto por decadência e expiação. Do mesmo modo que muitas crianças pequenas usam seus excrementos como um instrumento para afirmar a si próprias aos olhos dos adultos ao seu redor, vários dos artistas envolvidos na Body Art e performances também exaltam as funções excretoras e os usos e abusos de todos os orifícios corporais (Vergine, 2003, p. 909, tradução nossa).

A Body Art é intercambiável com o termo body modification, conforme demonstra Matthew C. Lodder (2010), observando que a primeira implica um processo de transformações estéticas que fazem do corpo ao mesmo tempo um evento artístico e o produto deste evento. Lodder (2010) examina a identificação dos modificadores corporais com os "modernos primitivos", lembrando que a expressão foi cunhada nos anos 1970 por Fakir Musafar, inspirado por práticas tribais de iniciação. Desde então, a "body modification" é associada aos movimentos de subcultura urbana promotora de rituais em que se interseccionam piercing, sadomasoquismo, tatuagem e cicatrização para demarcações de tipo grupal. Tais práticas, afirma Eric Gans (2003), são a atuação de sacrifícios rituais primitivos revisitados pela sociedade industrial e adaptados a histórias pessoais como formas de narrativa inscritas no corpo, plenas de potência erótica.

É sob a body modification e seus vínculos com erotismo, performance e martírio, que se debruça Newton Moreno no díptico Body Art, ambientado em São Paulo. Escrito na primeira década do século XXI, o texto encena as relações homoafetivas de um casal de body modificadoras e de fistfuckers, habitantes das zonas subterrâneas da cidade e que compartilham códigos e rituais que têm como princípio condutor "a carne em sacrifício" (Moreno, 2007, p. 93). Na primeira peça do díptico, "A cicatriz é a flor", Tatoo é a sacerdotisa que manobra o instrumento do rito, um bisturi, no corpo da Namorada, esculpindo-lhe os marcos de uma relação amorosa que chegara ao fim. A narrativa de Tatoo é escrita na pele por meio do procedimento da cicatrização, modificação corporal permanente e invasiva obtida através de incisões. Praticada em formas tribais de iniciação que marcam a aquisição de um conhecimento e a chegada a outro estágio de vida, trata-se de um rito que envolve dor e sacrifício voluntários, assim representado por Moreno (2008, p. 46):

A namorada desce o roupão, oferecendo-lhe a mama.

NAMORADA - A carne mais preciosa está sobre o coração.

Tatoo se prepara para cortá-la

NAMORADA (Em off) - Quando o sol se guarda para fora do teu lugar,

Lanço os balidos escuros das noites do meu sacrifício,

Torno-me a presa que se oferece alegre para o rito.

Sou a virgem a ser imolada

E vim com minhas próprias pernas,

Com a minha vontade.

TATOO (Em off) - Sou eu quem rezo ajoelhada à sua frente

Quem cava oráculos na tua pele

Espero o sol se guardar para fora de nosso lugar

Para entoar balidos,

Afiar minhas armas santas,

E acender incensos com o aroma do teu sangue

O rito sacrificial dramatizado em "A cicatriz é a flor" tem sua continuação em "Dentro" que, em linha com a exposição íntima da Body Art, encena a prática do fist-fucking. Assumindo a função condutora do ritual, antes desempenhada por Tatoo, um homem penetra com o punho o corpo de um rapaz, cujos orifícios corporais se tornam possibilidade de conhecimento do mundo e reivindicação de reconhecimento por parte do mundo: 
RAPAZ - Pode começar por onde quiser: todo o meu corpo é orifício. Várias portas. Cada poro deve ser penetrado pelo suor do outro com a mesma sensação de um membro, de uma língua, de dedos, mãos. Cada poro existe para me dar prazer. [...]

HOMEM - [...] Coloco minha mão à luz do sol, olhando a palma, as linhas, mas o que me impressiona é a sua firmeza. Sólida. Solto-a ao mar como uma rede de pesca. Curiosa. Ávida.

E eu a perdê-la de vista. Minha mão dentro do outro. Até o pulso. Ou além (Moreno, 2008, p. 56).

Se, em "A cicatriz é a flor", o rito é expresso no sacrifício consentido da Namorada, em "Dentro" as descrições dos apetites sexuais dos personagens vão trazendo à tona imagens sempre mais vívidas de canibalismos rituais. O "prazer carnal" ou prazer "pela carne" expresso duplamente pelas memórias amorosas do homem e pela representação do fist-fucking confirma a analogia entre o ato sexual e a deglutição canibal, potencializada pelo duplo significado da palavra "comer" na cultura brasileira:

Evoluí meu apetite por Binho. [...] Depois, sonhei que comia seus pedaços, alimentando-me de sua proteína albina. [...] Experimentei uma vontade de comê-lo. Sabê-lo inteiro: sabor, textura, tempero. Eu queria me imprimir em Binho, mostrar-lhe a minha fome (Moreno, 2008, p. 54).

Com as aproximações entre rito sacrificial, sexo e antropofagia, Body Art faz uma espécie de prelúdio ao tríptico $A$ refeição: ensaios dramáticos sobre o canibalismo, composto por " $1^{\circ}$ Movimento", "Cena 1: Nas selvas..." e "Cena 2: ... Das cidades".

O "10 Movimento" é ambientado em uma sala de hospital, onde uma moça se encontra hospitalizada após ter perdido um dedo da mão, consequência de um ato de canibalismo consentido. O prazer pela carne é a motivação erótica do ato, associada à intimidade sexual e à cumplicidade amorosa, pois se trata de um sacrifício corporal voluntário. De modo semelhante a Body Art, conhecer o outro é conhecer fisicamente o seu corpo, usufruindo de seus sabores, texturas e mistérios:

RAPAZ - Pus o dedo, mais ou menos 2/3 do dedo dentro da boca. Mordi levemente para demarcar o corte e deixei pesar a mandíbula, pesar bastante até romper o manto da pele.

Aos poucos um líquido inundou o paladar. Fui sentindo um gosto quase doce. Fui descendo a mordedura até que terminou a almofada da carne sua e os dentes caminhavam para se encontrar. Até que o osso exigiu mais força e eu rompi a carne frouxa e trouxe para mim. Lembro o sabor, lembro a textura, a suavidade, a maciez, a delicadeza como tudo se diluiu. Depois eu lembro do seu olhar perdido em mim, partilhando curiosa da mesma vontade. [...]

MOÇA - "Posso te morder? Posso arrancar um pedaço seu?"

O rapaz cede lentamente o dedo para a moça. Quando o dedo do rapaz está em frente à boca da moça, ela morde o dedo. Uma música suave acompanha o movimento. Luz baixa calmamente (Moreno, 2008, p. 66).

A segunda parte do tríptico exibe uma arquitetura social mais complexa. Ambientado na noite das sarjetas paulistanas, o texto coloca em cena o contraste entre um homem rico e um mendigo inconsciente. Diversamente de Body Art, "Cena 1: Na selva..." não representa um pacto sacrificial entre os personagens, mas simplesmente o martírio do mais fraco pelo mais forte, em direta decorrência de um abuso de classe:

HOMEM - [...] Mas eu tinha amigos ricos e perfumados. Amigos que adoravam rodar a cidade à noite e caçar bichos como você. Nossa adolescência não se desvirginou com putas, galinhas ou cabras. Nós disputávamos o rabo dos miseráveis. Pegávamos indigentes no meio da rua. O mendigo tinha que estar bem bêbado, daqueles que esqueceu a própria língua, o próprio nome, esqueceu até que está vivo. Tirávamos a sorte para ver quem iria primeiro. Mergulhávamos a cabeça dele num balde de pinga e comíamos o seu rabo pobre. Um após o outro. Foi assim que eu perdi a virgindade. O meu prazer nasceu no cu de uma lata de lixo, como o seu (Moreno, 2008, p. 68).

Também as mulheres são tratadas como objetos dos apetites carnais do homem rico, quer pela igualdade estabelecida entre prostitutas e animais estuprados, quer pelo comportamento violento do protagonista em relação à esposa, eliminada durante um ato sexual: 
Depois, é claro, eu tive uma mulher loira com uma boceta morena. [...] Numa noite, olhei para ela no meio da foda e implorei, sufocando-a aos poucos.

“O que eu queria te pedir é que você matasse uma pessoa e me amasse em seguida.

Queria o teu sangue veloz, porque matou uma pessoa, galopando até a caverna do meu pau. Inflando-o como um balão, de um sangue assassino. Você seria capaz de me dar esse sangue? E uivar faminta para o ouvido da noite?"

Ela calou. Puxei os cabelos loiros até aparecer a raiz morena. E ela se foi (Moreno, 2008, p. 70).

Deslocado do leito à sarjeta, o prazer do homem é obtido às custas da miséria de suas vítimas, cujo usufruto compra com comida ou esmolas. Se a "loira tingida" é o estereótipo do bem de luxo do homem de posses, os lugares comuns da miséria alojam as ideias pré-concebidas do "paulistano de bem" contra os migrantes, base sobre a qual se atua uma exclusão social justificada pelas ideias de excesso (de mão de obra, de gente, de criminalidade) ou descarte (a população tratada como lixo). Sobre eles, dentro deles, opera o falo disciplinadamente asséptico ${ }^{4}$ do homem rico:

Então, o mais próximo que me aproximei do lixo foi o cu de um boliviano. Ele me ofereceu o rabo em troca de um cachorro quente. Fiz questão de comê-lo enquanto ele devorava o sanduíche. Tinha tanta fome que não gritava, não gemia, não sentia. [...]

O outro foi um nordestino que eu conheci nos banheiros do Tietê. Ele falou que dava o cu para juntar a grana da passagem de volta. Que não arredava o pé da rodoviária até voltar. Que assim se sentia menos em 'Sum Paulo', que a rodoviária é terra de ninguém, que lá ainda era Pernambuco (Moreno, 2008, p. 70).

A violação corporal adquire contornos mais simbólicos no caso do nordestino, demonstrando a relação de sadismo entre o capitalista e o retirante pobre, representante de uma condição coletiva de miséria:

Eu comia o seu cu e mandava ele falar da seca, falar da fome, falar com sotaque, falar da miséria, falar dos filhos que morreram um a um e que ele enterrou junto dos pés secos de mandioca, falar de Graciliano Ramos, porra. Comi até mandá-lo de volta para a caatinga. A única coisa civilizada que ele levou embora foi meu sêmen, nadando dentro de seu rabo seco (Moreno, 2008, p. 71).

No monólogo, evidencia-se a recepção literária na citação de Graciliano Ramos. No trecho, a lembrança de uma literatura que fizera da representação do sertão um instrumento de denúncia da estrutura latifundiária do país, é destituída de toda potência trágica pela absoluta falta de pathos do poderoso em relação ao miserável. Sem nenhuma identificação possível entre o protagonista e aquele que, por ele, é destituído de humanidade, a fome, a miséria e a morte prematura são transformadas em meios de uma satisfação pessoal, executada como um privilégio de classe. Representante de uma elite financeira sediada na Av. Paulista - a elite do atraso de um capitalismo periférico - o homem rico clama para si o monopólio de uma civilidade da qual é a própria negação.

O voyeurismo do personagem que fetichiza a miséria conduz o discurso à relação canibalística: da analogia sexual - o ato de comer como penetração - o drama progride para a efetiva devoração do mais fraco. Esvaziando a relação simbólica do rito antropófago - em que a devoração era um pacto identitário entre fortes - o drama esvazia também a retórica modernista, que fazia da antropofagia ritual do passado uma elaboração metafórica daquela que prometia ser a força cultural da nação. No texto de Moreno, nada aponta para uma perspectiva redentora ou transcendente de país: "Cena 1. Nas selvas..." é encenado a partir de um olhar distópico, que vê no presente um impasse sem vias de superação. Assim, se nos ritos antropófagos o esquartejamento obedecia a um sistema simbólico, a peça de Moreno propõe secções quase cirúrgicas do corpo do miserável, tendo como único princípio organizador o desejo de posse do homem (branco, rico, publicamente heterossexual):

Eu te amei na primeira vez que você me pediu esmolas. [...]

O meu maior desejo... Eu acho que eu já te conheço o suficiente para te pedir.

(Pega-lhe a mão)

\footnotetext{
4 "Meu pau circuncizado e limpo três vezes ao dia. | Meu pau de pentelhos aparados simetricamente. | Meu pau de vitrine, meu pau asséptico" (Moreno, 2008, p. 70).
} 
Um pedaço teu. Um pedaço. Só um pedaço.

Você pode escolher qual.

Você tem que escolher, senão não seria amor.

Mas eu queria um pedaço bem sujo.

Os pés. As pernas. A carne do peito. A mama.

Os olhos! Me dá teus olhos sujos do mundo.

(De joelhos)

Foi assim que imaginei: você se divide em partes e prepara refeições a cada dia nosso juntos.

Café, almoço e jantar. Aos poucos, me ofereces metades e partículas. Carne gorda e cartilagens.

Ossos triturados, óleos de suas glândulas, caldos de prazer (Moreno, 2008, p. 72).

Autolegitimando-se através da exaltada eloquência amorosa, o personagem anula fisicamente a distância que o separa do outro, sem que nenhuma equiparação social seja atuada. Ao contrário, a supressão da distância é garantia do abuso do capitalista, que age sobre o outro com todo o peso de seu poder de barganha, não mais sobre o produto final que aliena da força de trabalho, mas sobre um corpo do qual reclama a possessão física. A linguagem com acentos pornográficos contribui para a fragmentação imaginária desse corpo seccionado em "rabo", "buceta", "cu". Violado primeiro pelo olhar fetichista que reifica e, em seguida, pelo falo agressor, o corpo deixa de corresponder à integridade de um sujeito para se transformar em objeto de manipulação. A representação de Moreno substitui, assim, o apelo mítico das leituras romântica e modernista da antropofagia pelo fetichismo autoindulgente, sádico e brutal do capitalista:

Tu sabes quem vem à noite cuidar de ti. Te nutrir.

Quem te adubou todo este tempo.

Para comer um naco de tua carne humana podre.

$[\ldots]$

Cada beijo que eu te dei foram ensaios desta mordida.

Mapeei minha fome na tua pele.

A primeira refeição.

(O mendigo oferece o dedo)

O teu dedo mindinho!

Confie em mim.

Prepara-se para a mordida. [...]

Ele morde o dedo do mendigo que geme de dor. O Homem com a boca suja de sangue mastiga o pedaço.

Em êxtase. [...]

O homem se joga sobre o mendigo como fera, agarrando a presa. Black out no pulo (Moreno, 2008, p. 73).

Nos momentos finais da peça, ouve-se, finalmente, a voz do mendigo. É um balbuciar "Embriagado de álcool e de dor" que assinala o seu lugar de vítima sacrificada à voracidade do mais forte:

Não quero mais dormir em uma vala de vômitos seus.

O que eu faria com a parte minha se você a vomitar?

Se sou alimento, me devora.

Me devora rápido antes que eu comece a sentir algo, antes que eu comece a me sentir algo, antes que eu comece a me sentir gente, antes que eu comece a me sentir vivo (Moreno, 2008, p. 73).

A refeição é concluído por "Cena 2... Das cidades", que pode ser lido como continuação do texto anterior pela sequencialidade dos títulos ("Cena 1" e "Cena 2", cujos subtítulos, unidos, formam "Na selva... ...Das cidades"). Temos, novamente, um homem (antropólogo, possivelmente branco e "civilizado") e um representante de uma categoria subalternizada: o agonizante Poru, último remanescente dos araweté. A referência modernista é clara: "poru”, em tupi antigo, significa "comer", sendo que "aba-poru" (comedor de gente) é o título da célebre tela de Tarsila do Amaral reproduzida ao centro do Manifesto Antropófago. Mas é impossível não lembrar também de Peri, antepassado literário que marca a incursão do herói indígena no romance brasileiro, com O Guarani, de José de Alencar. 
Em uma floresta do futuro - as árvores têm códigos de barra, representando a absolutização do controle exercido pelo capital - trava-se o diálogo entre o indígena e um cientista empenhado em registrar as suas últimas palavras, para que não se perca a memória dos araweté. Recusando qualquer tentativa de salvar a própria vida, Poru aceita que sua voz seja gravada, mas exige, em troca, que o antropólogo devore o seu corpo, após a morte. Moreno retorna, desta forma, a uma dimensão ritual da antropofagia. Não será através dos recursos tecnológicos do cientista, mas pelo ato final de deglutição, pelo retorno à prática ancestral canibalística, que Poru garantirá a transmissão de sua memória:

PORU - Voltei para encontrar meu povo e só me resta minha memória. Então eu obedeço a minha memória. Sigo cada atalho que ela me fornece. Cada sílaba. Para a volta. Eu lhe dou minhas palavras, mas o senhor me ajudará neste retorno e dará a honra de morrer como um Araweté (Moreno, 2008, p. 79).

Trata-se, evidentemente, de uma aproximação das leituras românticas do indianismo, sobretudo o de Gonçalves Dias, como se pode perceber na revisitação do topos da morte honrosa do bravo guerreiro, como no trecho que segue:

Quando morre um bravo, um homem de grandes feitos

Não se jogam seus restos na lama.

Dançamos sua morte de um sol a outro.

Vestimos os rostos com o preto azulado do jenipapo.

Venho de um tempo ermo, onde os que ficam

Cozinham o morto, preparando-o

E comem as partes

Durante uma noite e um dia inteiros.

Até lhe enterrarmos em nosso sangue.

Foi assim com meu tataravô.

Ele foi sepulto em sua gente.

Era assim que se honrava um homem.

Eu me lembro de seu sabor

De seu valor.

Quero que você me honre

Pedaço por pedaço.

Eu lhe dei minhas palavras

Lhe darei minhas últimas palavras

Preciosas palavras que deveriam morrer comigo

Mas este é o nosso acordo.

Você ressuscitará minha tribo com sua fome (Moreno, 2008, p. 83).

Assim como nos poemas gonçalveanos, o drama de Moreno representa a colonização a partir de uma perspectiva trágica que sinaliza a ruína dos povos indígenas. Eis, por exemplo, a descrição de Poru sobre o seu primeiro encontro com o invasor:

Achei feio e grande o primeiro branco

Tive medo quando ele abriu a boca

Disparou raios e trovões pela boca.

Falava como uma ameaça

Os sons anunciavam catástrofe

Naquele momento, o ar virou do avesso.

Era o som do fim (Moreno, 2008, p. 79).

Reaparece o tema da traição - assinalada por I-Juca Pyrama ao referir-se, aos estrangeiros "que vinham, traidores | com mostras de paz" (Dias, 1851, p. 35) -, presente na aparência enganadora da primeira palavra que Poru escutara de um homem branco: "Amigo" (Moreno, 2008, p. 79).

Com importância equiparável à do ato antropófago, a língua é demarcada como agente transmissor da memória dos mortos, que sussurram a Poru palavras esquecidas: 
PORU - Sy... Mãi... Aí... Começo a lembrar palavras empoeiradas de curumim. [...] Coisas ditas quando eu não tinha ciência dos brancos. Alguém da minha gente vem sussurrar meu idioma, revolver delicadamente a velha semente (Moreno, 2008, p. 76-77).

À língua indígena é contraposta a dos brancos, e cada palavra nova equivale ao desaparecimento de uma antiga. Materializando coisas ruins que, antes desconhecidas, foram trazidas pelos brancos, a nova língua assinala o esquecimento do passado:

Eu perdi minha mãe quando parei de ouvi-la.

Não entendia mais o que ela me dizia.

Não entendi quando ela me disse: 'filho, vou morrer'.

Perdi minha mãe

Porque aprendi a falar pela boca da sua gente [do antropólogo]

Ela deve ter gritado de dor e eu não ajudei.

Minha mãe diluiu-se no silêncio do meu passado

ela morreu de uma doença que não tinha

em nosso vocabulário

Um dia me vi órfão e não entendia o que me diziam. [...]

Eu tinha palavras lindas penduradas em cada galho da selva. Onde estão elas? Ybá... guyrá... caaeté... onde estão elas? (Moreno, 2008, p. 80-84).

Ao desespero do cientista, que vê agonizar o último remanescente de uma linhagem e que deseja registrar aquela língua que se perderá para sempre, Poru responde com a lembrança do pacto firmado entre os dois: após a sua morte, o antropólogo deve abrir-lhe a boca, beijar e mastigar-lhe a língua. A imagem sintetiza, desta forma, o ato canibal, entendido como transcendência e instrumento de transmissão de memória, funções normalmente atribuídas à linguagem. Aproxima-se, deste ponto de vista, ao entendimento antropológico da antropofagia tupi como sacrifício que é também construção identitária, forma de preservação da memória que confere à morte um sentido positivo de sobrevivência do grupo.

Se a "Cena 1..." é praticamente um monólogo do homem branco, a "Cena 2..." propõe a encenação de um diálogo, em que cabe a Poru o papel de protagonista. O personagem detém a palavra, e é o seu discurso que produz grande parte dos efeitos poéticos do texto, obtidos por uma qualidade estética que é negada à maioria das falas do antropólogo, caracterizadas por interferências pontuais, expressas em linguagem quotidiana. Quando morre Poru, todavia, a fala do cientista passa a ser expressa em versos livres - como era a do indígena -, recebendo um tratamento estilístico diverso, que confere ao texto maior espessura literária. Essa transformação na linguagem sinaliza, também, a continuidade estabelecida entre Poru e o antropólogo, receptor da carne do índio e da memória dos araweté, depositada agora no corpo do homem branco:

HOMEM - Eu honro sua memória e nosso sangue comum

Consagro a carne irmã

Alimento a nossa mesma estória.

No dia de minha morte,

Quem me devorará é a fraca memória dos vermes.

Mas hoje

Eu te como as partes em louvor.

Como o bravo, como o último

A sustentar tantos fantasmas.

Hoje morre uma tribo

Sem caravelas, sem febre, nem gripe, nem escravidão

Uma história do homem morre comigo (Moreno, 2008, p. 87).

\section{Considerações finais}

A tradição nas artes, conforme postula Jauss (1988, p. 26), se dá a partir de "um processo de intercambiável produção e recepção, de formação canônica e remodelamento, seleção do antigo e integração no novo". No caso do cânone brasileiro, um secular processo de recepção foi responsável 
pela formação de uma tradição aglutinada em torno do tema da antropofagia, transformando-a em uma constante característica de nosso sistema literário. Sem dar sinais de esgotar-se, tal tradição não se alimenta de um dado relevante da realidade nacional (os antropófagos estão, oficialmente, extintos), mas de figurações textuais do passado, atualizadas de vez em vez por novas interpretações que the atribuem funções e significados diversos de acordo com as necessidades do momento histórico em que reaparecem. Isso nos leva a concluir que, assim como as estruturas formais de um gênero, o reconhecimento de uma temática também depende do acordo implícito entre público e o autor, que parte de um horizonte familiar para dar-lhe novos desdobramentos estéticos, sob diversos pontos de vista éticos. Newton Moreno, a partir de relações implícitas com obras do passado, evoca o horizonte de expectativas de um público já familiarizado com os significados que a antropofagia assume na cultura literária brasileira, atualizando-a a partir do presente. Sua dramaturgia nos parece, assim, confirmar o processo de recepção no qual leituras acerca do ato antropófago dão origem a novos textos, num percurso de transmissão formador de uma tradição da qual Newton Moreno, renovando-a, é um intérprete. Familiarizado com conceitos próprios da cultura produzida pelas elites letradas do Brasil, Moreno desestabiliza-a, dando visibilidade poética a sujeitos e grupos marginalizados, denunciando ao mesmo tempo o poder de classe - e, com ele, de etnia e de gênero sancionador desta marginalidade.

\section{Referências}

AGNOLIN, Adone (2002). Antropofagia ritual e identidade cultural entre os Tupinambá. Revista de Antropologia, São Paulo, v. 45, n. 1, p. 132-185. Disponível em: http://www.scielo.br/pdf/ra/v45n1/a05v45n1.pdf. Acesso em: 15 maio 2018.

ALMEIDA, Maria Candida Ferreira de (2002). Tornar-se outro: o topos canibal na literatura brasileira. São Paulo: Annablume.

ANDRADE, Oswald de (1928). Manifesto Antropófago. Revista de Antropofagia, São Paulo, ano I, n. 1, p. 3-7. Disponível em: https:/ / bit.ly/2szY7SJ. Acesso em: 10 maio 2018.

ARTAUD, Antonin (1990). Alienar o ator. In: VIRMAUX, Alain. Artaud e o teatro. São Paulo: Perspectiva. p. 325-328.

ARTIOLI, Umberto (2004). Antonin Artaud e il teatro della crudeltà. In: ARTIOLI, Umberto. Il teatro di regia: genesi ed evoluzione (1870-1950). Roma: Carocci. p. 155-171.

CAMPOS, Haroldo (1992). Da razão antropofágica. In: CAMPOS, Haroldo. Metalinguagens e outras metas: ensaios de teoria e crítica literária. São Paulo: Perspectiva. p. 231-255.

CASTELLO, José Aderaldo (1965). Manifestações literárias da era colonial. São Paulo: Cultrix.

CASTRO, Eduardo Batalha Viveiros de (1986). Araweté: os deuses canibais. Rio de Janeiro: Jorge Zahar.

DIAS, Gonçalves. I Juca Pyrama (1851). In: DIAS, Gonçalves. Últimos cantos. Rio de Janeiro: Thypographia de F. de Paula Brito. p. 12-35. https:/ / bit.ly/2R9ketf. Acesso em: 10 maio 2018.

DURÃO, Santa Rita (1781). O Caramuru. Lisboa: Regia Officina Typografica. Disponível em: https:/ / bit.ly/2Y7hr5C. Acesso em: 10 maio 2018.

FERNANDES, Florestan (2006). A função social da guerra na sociedade tupinambá. São Paulo: Globo.

FREUD, Sigmund (2002). Totem e Tabù. In: FREUD, Sigmund. Opere 1905-1921. Roma: Newton \& Compton. p. 551-652.

GADAMER, Hans-Georg (2004). Verità e método. Milão: Bompiani.

GANS, Eric (2003). The body sacrificial. In: SIEBERS, Tobin (Org.). Body aesthetic: from fine arts to body modification. Michigan: University of Michigan. p. 159-179.

ISER, Wolfgang (1987). L'atto della lettura: una teoria della risposta estetica. Bolonha: Il Mulino. 
ISER, Wolfgang (1989). Il processo della lettura. In: HOLUB, Robert C. (Org.). Teoria della ricezione. Torino: Einaudi. p. 43-69.

JAUSS, Hans Robert (1988). Estetica della ricezione. Nápolis: Guida Editori.

JAUSS, Hans Robert (1989). La teoria della ricezione. Identificazione retrospettiva dei suoi antecedenti storici. In: HOLUB, Robert. C. (Org.). Teoria della ricezione. Torino: Einaudi. p. 3-26.

JAUSS, Hans Robert (1994). A história da literatura como provocação à teoria literária. São Paulo: Ática.

LODDER, Matthew C. (2010). Body art: body modification as artistic practice. Tese (Doutorado em História da Arte) - University of Reading, Reading. Disponível em: https://bit.ly/2Y6Rp2e. Acesso em: 10 maio 2018.

MACHADO, Antonio de Alcântara. (1928) Abre Alas. Revista de Antropofagia, São Paulo, ano I, n. 1, p. 1, maio. https:/ / bit.ly/2Y9ND8q. Acesso em: 10 maio 2018.

MATTEI, Anna (1988). Introduzione. In: JAUSS, Hans Robert. Estetica della ricezione. Nápolis: Guida Editori. p. 5-19.

MERQUIOR, José Guilherme (2014). De Anchieta a Euclides: breve história da literatura brasileira. São Paulo: É Realizações.

MORENO, Newton (2007). Agreste: uma nostalgia das origens. Algumas/rápidas considerações sobre o processo criativo do texto Agreste. Sala Preta, ano I, n. 4. p. 92-96. Disponível em: https://bit.ly/34E5xm3. Acesso em: 6 fev. 2016.

MORENO, Newton. Agreste, Body Art, A refeição. São Paulo: Aliança Francesa; Imprensa Oficial do Estado de São Paulo, 2008.

PAPPALARDO, Ferdinando (2009). Teoria dei generi letterari. Bari: B. A. Graphis.

REIS, Roberto (1992). Cânon. In: JOBIM, José Luís (Org.). Palavras da crítica. Rio de Janeiro: Imago. p. 65-92.

RIBEIRO, Darcy (2006). O povo brasileiro. São Paulo: Companhia das Letras.

VÁZQUEZ, Adolfo Sánchez (2005). De la estética de la recepción a una estética de la participación. Cidade do México: Universidade Autônoma do México.

VERGINE, Lea (2003). The body as language. In: HARRISON, Charles; WOOD, Paul (Org.). Art in theory: 1900-2000 an anthology of changing ideas. Oxford: Blackwell. p. 906-910.

VIRMAUX, Alain (1990). Artaud e o teatro. São Paulo: Perspectiva. 